\title{
Pengembangan Perangkat Pembelajaran Problem Based LEARNING DAN HYPOTHETICAL LEARNING TRAJECTORY YANG BERORIENTASI PADA KEMAMPUAN PENALARAN MATEMATIS SisWA
}

\author{
Khoirudin $^{1}$ dan Ilham Rizkianto ${ }^{2}$ \\ 1Jurusan Pendidikan Matematika, Universitas Negeri Yogyakarta \\ Jl. Colombo No. 1, Karangmalang, Yogyakarta 55281, Indonesia \\ khoirudin945fmipa@student.uny.ac.id \\ 2Jurusan Pendidikan Matematika, Universitas Negeri Yogyakarta \\ Jl. Colombo No. 1, Karangmalang, Yogyakarta 55281, Indonesia \\ ilham_rizkianto@uny.ac.id
}

\begin{abstract}
Abstrak
Penelitian ini adalah research and development (R\&D) yang bertujuan untuk mengembangkan perangkat pembelajaran berupa RPP dan LKS dengan pendekatan problem based learning dan hypothetical learning trajectory yang berorientasi pada kemampuan penalaran matematis siswa. Subjek penelitian ini adalah siswa kelas VII A SMP Negeri 1 galur dengan jumlah siswa sebanyak 22 siswa. Prosedur pengembangan penelitian ini adalah model ADDIE yang terdiri dari Analysis, Design, Development, Implementation, dan Evaluation. RPP dan LKS yang telah dikembangkan divalidasi dan direvisi sehingga layak untuk digunakan. Berdasarkan hasil penilaian kevalidan, RPP memenuhi kriteria sangat valid, sedangkan LKS memenuhi kriteria valid. Berdasarkan hasil penilaian kepraktisan, perangkat pembelajaran memenuhi kriteria sangat praktis dengan perolehan skor angket respon siswa 3,38 pada skala 4 dan angket respon guru 3,73 pada skala 4. Berdasarkan penilaian keefektifan dari tes kemampuan penalaran matematis diperoleh nilai ratarata kelas yaitu 88 dan siswa yang memperoleh nilai minimal pada kategori "baik" sebesar $91 \%$. Keefektifan perangkat pembelajaran pada kemampuan penalaran matematis didukung oleh one sample t-test dengan taraf signifikansi 0,05.

Kata Kunci: perangkat pembelajaran, problem based learning, hypothetical learning trajectory, kemampuan penaralan matematis
\end{abstract}

\begin{abstract}
This research is a research and development (R\&D) which aim to develop mathematics learning material that includes lesson plans and student worksheets based on problem based learning approach and hypothetical learning trajectory with an orientation on students' mathematical reasoning skill. The subjects of this study were the students of class VII A SMP Negeri 1 Galur with a total of 22 students. The present study used ADDIE model, consisting of Analysis, Design, Development, Implementation, and Evaluation. The lesson plans and student worksheets were validated and undergone several revisions to obtain appropriate results for use. Based on the result of validation assessment, the lesson plan is "very valid", while validation assessment of student worksheets is "valid". Based on the result of practicality, learning material is "very practical" with 3.38 on a scale 4 of student questionnaire and 3.73 on a scale 4 of teacher questionnaire. Based on the effectiveness assessment using mathematical reasoning student's skill test, the average score of the class is 88 and $91 \%$ of students have minimum mathematical reasoning skill in the "good" category. The effectiveness of the learning material on mathematical reasoning student's skill is also proved by one sample t-test with level of significant 0.05 .

Keyword: learning material, problem based learning, hypothetical learning trajectory, students' mathematical reasoning skill
\end{abstract}


http://journal.institutpendidikan.ac.id/index.php/mosharafa

\section{Pendahuluan}

Matematika sangat diperlukan baik dalam kehidupan sehari-hari maupun dalam menghadapi kemajuan IPTEK sehingga matematika perlu dibekalkan kepada siswa pada jenjang pendidikan dasar maupun pada jenjang pendidikan menengah (Solihah, 2016: 47). Salah satu kompetensi yang diharapkan setelah siswa mempelajari matematika di pendidikan dasar dan pendidikan menengah adalah siswa mampu melakukan penalaran matematis (Kemenikbud, 2017). Penalaran merupakan suatu proses berpikir untuk menarik suatu kesimpulan (Shadiq, 2004: 2). Dalam dokumen National Council of Teacher of Mathematics (NCTM, 2000), terdapat lima standar proses dalam pembelajaran matematika, yaitu problem solving (pemecahan masalah), (2) reasoning and proof (penalaran dan pembuktian), (3) communication (komunikasi), (4) connection (koneksi), dan (5) representation (representasi).

Kemampuan siswa Indonesia dalam melakukan penalaran matematika dapat dilihat dari hasil studi Trends in International Mathematics and Science Study (TIMSS). Menurut hasil TIMSS (timss.bc.edu), pada tahun 2003, hasil studi TIMSS menunjukkan peserta didik Indonesia memperoleh nilai 379, sedangkan nilai TIMSS rata-rata internasional 500. Selanjutnya, hasil studi TIMSS tahun 2007, Indonesia memperoleh nilai 411, sedangkan nilai TIMSS rata-rata internasional 467. Kemudian, TIMSS 2011, Indonesia memperoleh nilai 386, sedangkan nilai TIMSS rata-rata internasional 500. Berdasarkan data tersebut, Indonesia belum pernah mencapai nilai rata-rata internasional pada TIMSS tahun 2003, 2007, dan 2011.

Berdasarkan data penelitian World Bank Indonesia (2010: 2) mengenai kegiatan pembelajaran matematika dan capaian siswa di Indonesia, rasio percakapan guru kepada siswa jauh lebih tinggi daripada negara-negara lain. Guru Matematika di Indonesia mengucapkan 25 kata untuk setiap satu kata yang diucapkan siswa.

Pembelajaran matematika di dalam kelas masih didominasi oleh guru dan siswa belum berperan aktif. Hamid (2011: 210) juga berpendapat bahwa kelemahan dari metode ceramah atau ekspositori adalah menyebabkan siswa menjadi pasif.

Salah satu pendekatan yang memfasilitasi siswa agar aktif dalam pembelajaran matematika adalah pendekatan problem based learning (PBL). Hal ini sesuai dengan pendapat Miao, et al. (2000: 232) yaitu PBL merupakan metode pengajaran yang semakin populer dan mengharuskan peserta didik untuk secara aktif mengumpulkan serta menerapkan pengetahuan untuk menyelesaikan permasalahan yang tidak terstruktur dalam kehidupan sehari-hari. Hal ini sejalan dengan pendapat Julita (2018: 152) bahwa salah satu kelebihan PBL yaitu peserta didik menjadi lebih tertantang kemampuannya untuk berusaha menyelesaikan permasalahan. 
Guru mempunyai peranan penting dalam membantu siswa untuk meningkatkan kemampuan belajar mereka. Berdasarkan Permendiknas Nomor 41 Tahun 2007 tentang Standar Proses untuk Satuan Pendidikan Dasar dan Menengah, setiap guru pada satuan pendidikan berkewajiban menyusun RPP secara lengkap dan sistematis. Selain RPP, guru juga harus menyediakan LKS yang inovatif dan tidak hanya berisi tentang soal-soal latihan.

RPP yang baik, salah satunya disusun dengan mempertimbangkan hipotesis lintasan belajar siswa. Hipotesis lintasan belajar sering disebut dengan istilah hypothetical learning trajectory (HLT). Guru yang memahami HLT pasti akan memahami pembelajaran matematika, memahami bagaimana siswa berpikir, memahami bagaimana siswa belajar matematika, dan memahami bagaimana membantu siswa untuk mempelajari matematika dengan lebih baik (Clements \& Sarama, 2009: p.ix). Menurut Simon (1995: 136), tiga komponen penting dalam HLT yaitu tujuan pembelajaran, aktivitas pembelajaran dan hipotesis berpikir siswa. Dengan adanya HLT maka guru dapat menduga pemahaman siswa terkait materi yang akan dipelajari.

Berdasarkan observasi lapangan yang dilakukan di SMP Negeri 1 Galur, sekolah tersebut sudah menerapkan Kurikululum 2013 dan menggunakan Buku Siswa dan Buku Guru Matematika SMP/MTs Kelas VII Semester 2 Edisi Revisi 2016 terbitan Kemendikbud. Akan tetapi, pada pelaksanaannya, proses pembe-lajaran masih dominan menggunakan metode ekspositori dan soal-soal yang disajikan guru kepada siswa sebatas soal yang bersifat prosedural sehingga belum memfasilitasi siswa untuk menyelesaikan soal yang menuntut kemampuan penalaran matematis. Selain itu, berdasarkan analisis dokumen RPP guru, perangkat pembelajaran yang digunakan belum memuat dugaan-dugaan respon siswa yang muncul ketika proses pembelajaran.

Dari uraian tersebut maka perlu pengembangan perangkat pembelajaran berupa RPP dan LKS. LKS yang dikembangkan dibuat berdasarkan pada sintaksis PBL. Sedangkan RPP yang dikembangkan dibuat berdasarkan pendekatan PBL dan mengacu pada HLT. Sintaksis PBL yang digunakan pada penelitian ini mengacu pada sintaksis Arends (2012: 411) sebagai berikut:

Fase 1: Memberikan orientasi tentang permasalahan kepada siswa.

Fase 2: Mengorganisasikan siswa untuk meneliti.

Fase 3: Membantu investigasi mandiri dan kelompok.

Fase 4: Mengembangkan dan mempresentasikan produk hasil diskusi.

Fase 5: Menganalisis dan mengevaluasi proses penyelesaian masalah.

Perangkat pembelajaran yang dikembangkan diharapkan dapat memfasilitasi siswa untuk mengembangkan kemampuan penalaran 
matematis. Pada penelitian ini, indikator kemampuan penalaran matematis yang digunakan adalah (1) kemampuan manipulasi matematika; (2) kemampuan memberikan alasan; (3) kemampuan menyusun kesimpulan. Indikator tersebut mengacu pada Peraturan Dirjen Dikdasmen Depdiknas Nomor 506/C/Kep/PP/2004 (Wardhani, 2008: 14).

\section{Metode}

Jenis penelitian yang dilakukan adalah Research and Development (R\&D). Model pengembangan yang digunakan adalah model pengembangan ADDIE. Langkahlangkah yang terdapat dalam model pengembangan ini menurut Dick \& Carey (2009) adalah Analysis, Design, Development, Implementation, dan Evaluation.

Penelitian dilaksanakan pada tanggal 15 Februari 2018 sampai dengan 1 Maret 2018. Tempat penelitian di SMP Negeri 1 Galur yang beralamat di Kecamatan Galur, Kabupaten Kulon Progo, Provinsi DIY. Populasi penelitian ini adalah seluruh siswa kelas VII SMP Negeri 1 Galur tahun ajaran 2017/2018 yang terdiri dari 6 kelas. Kemudian, dipilih sampel secara acak sebanyak satu kelas. Hasilnya, didapatkan sampel kelas untuk peneltian yaitu kelas VII A yang memiliki siswa sejumlah 22 .

Jenis data pada penelitian ini adalah kualitatif dan kuantitatif. Data kualitatif berupa deskripsi tanggapan dan masukan respon dari validator ahli mengenai perangkat pembelajaran yang dibuat dan pengisian lembar observasi keterlaksanaan pembelajaran. Sedangkan data kuantitatif berupa skor hasil angket respon, penilaian perangkat pembelajaran oleh validator, serta hasil tes kemampuan penalaran matematis.

Instrumen yang digunakan dalam penelitian ini adalah (1) instrumen untuk mengukur kevalidan berupa lembar penilaian LKS dan lembar penilaian RPP; (2) instrumen untuk mengukur kepraktisan berupa angket respon siswa dan angket respon guru; (3) instrumen untuk mengukur keefektifan yaitu data hasil tes kemampuan penalaran matematis siswa yang telah difasilitasi dengan perangkat pembelajaran yang dikembangkan; (4) lembar observasi keterlaksanaan pembelajaran yang digunakan sebagai data pendukung kesesuaian keterlaksanaan pembelajaran dengan perangkat pembelajaran yang dikembangkan.

Data kuantitatif berskala 5 dikonversikan menjadi data kualitatif menggunakan acuan rumus (Widoyoko, 2017: 238) sebagai berikut.

Tabel 1.

Konversi Skor Penilaian Skala 5

\begin{tabular}{cc|}
\hline Rentang Skor & Kategori \\
\hline $\bar{x}>\mathbf{4 , 2}$ & Sangat Baik \\
\hline $\mathbf{3 , 4}<\overline{\boldsymbol{x}} \leq \mathbf{4 , 2}$ & Baik \\
\hline $\mathbf{2 , 6} \overline{\boldsymbol{x}} \leq \mathbf{3 , 4}$ & Cukup \\
\hline $\mathbf{1 , 8} \mathbf{8}<\overline{\boldsymbol{x}} \leq \mathbf{2 , 6}$ & Kurang \\
\hline$\overline{\boldsymbol{x}}>\mathbf{1 , 8}$ & Sangat Kurang \\
\hline
\end{tabular}

Keterangan: $\bar{x}=$ rata-rata perolehan skor

Sedangkan data kuantitatif berskala 4 dikonversikan menjadi data kualitatif menggunakan acuan rumus (Widoyoko, 2017: 238) sebagai berikut. 
Tabel 2.

Konversi Skor Penilaian Skala 4

\begin{tabular}{|cc|}
\hline \multicolumn{1}{c}{ Rentang Skor } & Kategori \\
\hline$\overline{\boldsymbol{x}}>\mathbf{3}, \mathbf{4}$ & Sangat Baik \\
\hline $\mathbf{2 , 8}<\overline{\boldsymbol{x}} \leq \mathbf{3 , 4}$ & Baik \\
\hline $\mathbf{2 , 2} \overline{\mathbf{x}} \leq \mathbf{2 , 8}$ & Cukup \\
\hline $\mathbf{1 , 6}<\overline{\boldsymbol{x}} \leq \mathbf{2 , 2}$ & Kurang \\
\hline$\overline{\boldsymbol{x}}>\mathbf{1 , 6}$ & Sangat Kurang \\
Keterangan: $\bar{x}$ = rata-rata perolehan skor
\end{tabular}

Perangkat pembelajaran dapat dikatakan valid jika rata-rata penilaian oleh validator berada minimal pada kategori "baik". Selanjutnya, perangkat pembelajaran dikatakan praktis jika hasil data respon siswa dan guru minimal pada kategori "baik". Kemudian, perangkat pembelajaran dikatakan efektif jika hasil tes kemampuan penalaran matematis siswa memenuhi minimal kategori baik, persentase yang memenuhi minimal kategori baik lebih dari 75\%, dan perolehan nilai rata-rata kelas lebih dari 70.

\section{Hasil dan Pembahasan}

\section{A. Hasil}

1. Tahap Analisis (Analysis)

Kompetensi yang digunakan dalam pembelajaran matematika di SMP 1 Galur kelas VII mengacu pada Kurikulum 2013. Berdasarkan hasil observasi pembelajaran, siswa aktif dalam pembelajaran. Hal tersebut ditunjukkan dengan siswa aktif dalam diskusi kelas, siswa sudah membaca materi yang akan dipelajari pada setiap pertemuan, dan terdapat minimal dua siswa yang bertanya jika ada materi yang belum paham. Hal tersebut terlihat dari pertanyaan yang diajukan siswa yaitu
"Bagaimana cara menggambar sudut $105^{\circ}$ ?". Terdapat juga siswa yang mempunyai kemampuan tinggi dan rendah. Hal ini terlihat dari satu dari tiga siswa yang maju mengerjakan soal masih salah.

Ruang kelas VII A berada di sudut lantai dua dan tidak terganggu oleh kegiatan pembelajaran kelas lain. Jumlah siswa tidak terlalu banyak yaitu 22 siswa. Hal tersebut sesuai dengan Permendikbud Nomor 23 Tahun 2013 tentang Standar Pelayanan Minimal Pendidikan Dasar di Kabupaten/Kota yang menerangkan bahwa jumlah peserta didik dalam rombongan belajar untuk SMP/MTs tidak melebihi 36 orang.

Siswa belajar menggunakan buku Matematika SMP/MTs Kelas VII Semester 2 Edisi Revisi 2016. Perangkat pembelajaran yang digunakan yaitu RPP, LKS yang berisikan soal-soal, buku siswa dan buku guru. Berdasarkan observasi di kelas, 4 dari 5 pertemuan, guru menjelaskan materi melalui power point yang berisi materi dan soal dari Buku Siswa Matematika SMP/MTs Kelas VII Semester 2 Edisi Revisi 2016. Kemudian, guru meminta siswa untuk menyelesaiakan soal-soal yang ditampilkan pada power point. Selain itu, guru belum memperhatikan beberapa kemungkinan alur belajar siswa. Hal tersebut berdasarkan analisis dokumen RPP yang dimiliki guru bahwa RPP yang digunakan tidak memuat dugaan-dugaan kemungkinan perbedaan alur belajar siswa. 
2. Tahap Perancangan (Design)

Hasil analisis digunakan untuk dasar menyusun perangkat pembelajaran. Pada tahap ini dilakukan perancangan perangkat pembelajaran yang berupa RPP dan LKS. RPP dikembangkan menurut prinsip pengembangan RPP berdasarkan Permendikbud Nomor 81A Tahun 2013 tentang Implementasi Kurikulum Pedoman untuk Pembelajaran. Prinsip penyusunan RPP berdasarkan Permendikbud Nomor 22 Tahun 2016 tentang Standar Proses Pendidikan Dasar dan Menengah. Kemudian, KI (Kompetensi Inti) dan KD (Kompetensi Dasar) mengacu pada Permendikbud Nomor 24 Tahun 2016 tentang Kompetensi Inti dan Kompetensi Dasar Pelajaran Kurikulum 2013 Pada Pendidikan Dasar dan Pendidikan Menengah.

Perangkat pembelajaran disesuaikan sintaksis dengan pendekatan PBL menurut Arends. Perangkat pembelajaran juga mengacu pada komponen HLT menurut Simon (1995: 136). Pada RPP dilengkapi kolom respon siswa dan alternatif respon guru sebagai komponen dari hipotesis berpikir siswa.

Pengembangan LKS disusun dengan memperhatikan aspek didaktik, konstruksi, teknis, materi, dan kesesuaian LKS dengan pendekatan PBL mengacu pada HLT yang telah dibuat setelah melakukan observasi.

3. Tahap Pengembangan (Development)

Pada tahap ini dilakukan realisasi kerangka produk untuk menjadi produk yang siap untuk diimplementasikan. Selain itu, juga dilakukan validasi produk oleh dosen ahli dan guru matematika terhadap RPP dan LKS. Masukan dari dosen ahli dan guru matematika dijadikan bahan untuk merevisi RPP dan LKS yang dikembangkan. Hasil penilaian RPP dan LKS oleh validator memiliki skor maksimal 5 dan disajikan dalam Tabel 3 dan 4.

Tabel 3.

Hasil Analisis Penilaian RPP

\begin{tabular}{lcc|}
\hline \multicolumn{1}{c}{$\begin{array}{c}\text { Aspek } \\
\text { Penilaian }\end{array}$} & $\begin{array}{c}\text { Skor } \\
\text { Rata-Rata }\end{array}$ & Kategori \\
\hline $\begin{array}{l}\text { Identitas RPP } \\
\begin{array}{l}\text { Indikator dan } \\
\text { Tujuan } \\
\text { Pembelajaran }\end{array}\end{array}$ & 4,95 & SB \\
\hline \begin{tabular}{l} 
Materi Pokok \\
\hline Alokasi Waktu
\end{tabular} & 4 & B \\
\hline $\begin{array}{l}\text { Metode } \\
\text { Pembelajaran }\end{array}$ & 4 & B \\
\hline $\begin{array}{l}\text { Media } \\
\text { Pembelajaran } \\
\text { dan Sumber } \\
\text { Belajar }\end{array}$ & 3,75 & B \\
\hline $\begin{array}{l}\text { Langkah- } \\
\text { Langkah } \\
\text { Kegiatan } \\
\text { Pembelajaran }\end{array}$ & 4 & B \\
\hline Penilaian & 4,25 & SB \\
\hline $\begin{array}{l}\text { Kesimpulan } \\
\text { Keterangan: B (Baik), SB (Sangat Baik) }\end{array}$ & \\
\hline
\end{tabular}

Tabel 4.

Hasil Analisis Penilaian LKS

\begin{tabular}{lcc|}
\hline \multicolumn{1}{c}{$\begin{array}{c}\text { Aspek } \\
\text { Penilaian }\end{array}$} & $\begin{array}{c}\text { Skor } \\
\text { Rata-Rata }\end{array}$ & Kategori \\
\hline $\begin{array}{l}\text { Kesesuaian dengan } \\
\text { syarat didaktik }\end{array}$ & 4 & B \\
\hline $\begin{array}{l}\text { Kesesuaian dengan } \\
\text { syarat konstruksi }\end{array}$ & 4,33 & SB \\
\hline $\begin{array}{l}\text { Kesesuaian dengan } \\
\text { syarat teknis }\end{array}$ & 3,9 & B \\
\hline Kesesuaian materi & 4 & B \\
\hline
\end{tabular}




\begin{tabular}{l}
$\begin{array}{l}\text { Kesesuaian LKS } \\
\text { dengan }\end{array}$ \\
$\begin{array}{l}\text { pendekatan } \\
\text { problem based }\end{array}$ \\
$\begin{array}{l}\text { learning mengacu } \\
\text { pada learning } \\
\text { trajectory }\end{array}$ \\
$\begin{array}{l}\text { Kesimpulan } \\
\text { 4,05 }\end{array}$ \\
\hline
\end{tabular}

Keterangan: B (Baik), SB (Sangat Baik)

Berdasarkan Tabel 3 dan 4, RPP dan LKS yang dikembangkan memenuhi kategori minimal baik sehingga valid untuk diujicobakan.

4. Tahap Implementasi (Implementation)

Hasil dari tahap ini adalah hasil respon siswa, respon guru, tes kemampuan penalaran matematis siswa, dan data observasi keterlaksanaan pembelajaran.

5. Tahap Evaluasi (Evaluation)

Hasil dari tahap evaluasi adalah hasil analisis kepraktisan dan keefektifan dari perangkat pembelajaran yang dikembangkan. Hasil angket respon siswa dan guru terhadap perangkat pembelajaran yang telah digunakan memiliki skor makimal 4 dan dapat dilihat pada Tabel 5 dan 6.

Tabel 5. Hasil Analisis Angket Respon Siswa

\begin{tabular}{lcc|}
\hline \multicolumn{1}{c}{ Aspek Penilaian } & $\begin{array}{c}\text { Skor } \\
\text { Rata-Rata }\end{array}$ & Kategori \\
\hline Keterbantuan & 3,64 & SB \\
\hline Materi/Isi LKS & 3,44 & SB \\
\hline Kemudahan & 3,29 & SB \\
\hline Kemenarikan & 3,38 & SB \\
\hline Kesimpulan & 3,44 & SB \\
Keterangan: B (Baik), SB (Sangat Baik) & \\
\hline
\end{tabular}

Tabel 6.

Hasil Analisis Angket Respon Guru

\begin{tabular}{lll|}
\hline Aspek Penilaian & Skor Rata-Rata & Kategori \\
\hline Materi & 4 & SB \\
\hline RPP & 3,57 & SB \\
\hline LKS & 3,73 & SB \\
\hline Kesimpulan & 3,73 & SB \\
\hline \multicolumn{2}{l}{ Keterangan: B (Baik), SB (Sangat Baik) }
\end{tabular}

Berdasarkan Tabel 5 dan 6, dapat dilihat bahwa skor penilaian rata-rata siswa terhadap perangkat pembelajaran adalah 3,44. Sedangkan skor penilaian rata-rata guru terhadap perangkat pembelajaran adalah 3,73. Penilaian siswa dan guru masuk dalam kategori sangat baik sehingga dapat dikatakan bahwa perangkat pembelajaran yang dikembangkan praktis untuk digunakan dalam pembelajaran.

Keefektifan perangkat pembelajaran adalah sebagai berikut.

1. Hasil tes kemampuan penalaran matematis siswa minimal pada kategori baik.

Tabel 7.

Hasil Analisis Butir Kemampuan Penalaran Matematis

\begin{tabular}{|c|c|c|}
\hline $\begin{array}{c}\text { Aspek } \\
\text { Penilaian }\end{array}$ & $\begin{array}{c}\text { Persentase } \\
\text { Ketercapaian }\end{array}$ & Kategori \\
\hline $\begin{array}{c}\text { Kemampuan } \\
\text { manipulasi } \\
\text { matematika }\end{array}$ & $88 \%$ & SB \\
\hline $\begin{array}{c}\text { Kemampuan } \\
\text { memberikan } \\
\text { alasan }\end{array}$ & $84 \%$ & SB \\
\hline $\begin{array}{c}\text { Kemampuan } \\
\text { menyusun } \\
\text { kesimpulan }\end{array}$ & $90 \%$ & SB \\
\hline Kesimpulan & $88 \%$ & SB \\
\hline
\end{tabular}


Berdasarkan Tabel 7, diperoleh bahwa persentase ketercapaian tiap aspek kemampuan penalaran matematis sudah mencapai kategori sangat baik.

2. Persentase yang memenuhi minimal kategori baik lebih dari $75 \%$

Tabel 8

Hasil Analisis Tes Kemampuan Penalaran

Matematis

\begin{tabular}{|c|c|}
\hline Aspek Penilaian & Hasil \\
\hline \multicolumn{2}{|l|}{ Perolehan Nilai Siswa } \\
\hline a. Nilai tertinggi & 100 \\
\hline b. Nilai Terendah & 64 \\
\hline c. Rata-rata Nilai & 88 \\
\hline \multicolumn{2}{|l|}{ Keuntasan Siswa } \\
\hline a. Banyak Siswa Tuntas & 20 \\
\hline $\begin{array}{l}\text { b. Banyak Siswa Tidak } \\
\text { Tuntas }\end{array}$ & 2 \\
\hline c. Persentase Ketuntasan & $91 \%$ \\
\hline d. Kriteria & Sangat Baik \\
\hline
\end{tabular}

Berdasarkan Tabel 8, hasil tes kemampuan penalaran matematis memiliki persentase ketuntasan minimal pada kategori baik yaitu sebesar 91\%. Artinya, perangkat pembelajaran memenuhi kriteria keefektifan bahwa siswa yang memenuhi minimal kategori baik lebih dari 75\%.

3. Perolehan nilai rata-rata kelas lebih dari 70

Tingkat keefektifan perangkat pembelajaran diuji dengan melakukan perhitungan uji normalitas dan uji t. Uji normalitas dilakukan dengan uji onesample Kolmogorov-Smirnov test dengan menggunakan bantuan software SPSS statistic. Hasil uji normalitas didapatkan taraf signifikansi $=0,358>\alpha=0,05$. Artinya, data berasal dari populasi yang berdistribusi normal. Sedangkan uji hipotesis menggunakan statistik uji one sample t-test dengan menggunakan bantuan software SPSS statistic.

Berdasarkan uji hipotesis, taraf signifikansi $=0,000<\alpha=0,05$. Artinya, nilai rata-rata tes kemampuan penalaran matematis siswa lebih dari 70. Oleh karena itu, dapat disimpulkan bahwa perangkat pembelajaran yang dikembangkan efektif.

Hasil analisis lembar observasi keterlaksanaan pembelajaran disajikan dalam Tabel 9.

Tabel 9.

Hasil Analisis Lembar Observasi Keterlaksanaan Pembelajaran

\begin{tabular}{|ccc|}
\hline Pertemuan ke- & $\begin{array}{c}\text { Persentase } \\
\text { Keterlaksanaan }\end{array}$ & Kategori \\
\hline 1 & $100 \%$ & Sangat Baik \\
\hline 2 & $100 \%$ & Sangat Baik \\
\hline 3 & $100 \%$ & Sangat Baik \\
\hline 4 & $93 \%$ & Sangat Baik \\
\hline Kesimpulan & $98 \%$ & Sangat Baik \\
\hline
\end{tabular}

Berdasarkan Tabel 9, diperoleh bahwa persentase rata-rata keterlaksanaan pembelajaran sebesar 98\%. Artinya, keterlaksanaan pembelajaran termasuk dalam kategori sangat baik. Hal ini menunjukkan bahwa pelaksanaan pembelajaran sesuai dengan perangkat pembelajaran yang dikembangkan.

\section{B. Pembahasan}

Langkah-langkah pembelajaran merujuk pada langkah PBL menurut Arends (2012: 411) yang terdiri dari fase 1 sampai fase 5 . LKS berisi kegiatan-kegiatan yang mewakili fase 1 sampai fase 5 . Fase 1 diwakili dengan kegiatan "Ayo Mengamati", fase 2 diwakili kegiatan "Ayo Selidiki", fase 3 
diwakili kegiatan "Ayo Berdiskusi" dan "Ayo Simpulkan", fase 4 diwakili kegiatan "Ayo Presentasikan" serta fase 5 diwakili kegiatan "Ayo Berlatih".

Langkah kegiatan pembelajaran RPP merujuk pada LKS yang telah dikembangkan. RPP yang dikembangkan juga dilengkapi kolom dugaan respon siswa dan kolom alternatif respon guru karena salah satu komponen dalam HLT menurut Simon (1995: 136) adalah adanya dugaan alur berpikir siswa. Salah satu contoh hal yang muncul ketika siswa kesulitan untuk melakukan kegiatan "Ayo Menyimpulkan" yaitu siswa tidak bisa menjawab hubungan antara bruto, neto, dan tara. Kemudian, guru membimbing siswa dengan pertanyaan-pertanyaan seperti pada Gambar 1.

\begin{tabular}{|l|c|}
\hline Siswa tidak dapat & Guru membimbing siswa \\
menuliskan & melalui pertanyaan: \\
kesimpulan tentang & - "Jika diketahui neto \\
hubungan neto, & dan bruto, bagaimana \\
bruto, dan tara. & menentukan tara"? \\
& $\begin{array}{c}\text { "Jika diketahui neto } \\
\text { dan tara, bagaimana } \\
\text { menentukan bruto"? } \\
\text { "Jika diketahui tara } \\
\text { dan bruto, bagaimana } \\
\text { menentukan neto"? }\end{array}$ \\
\hline
\end{tabular}

Gambar 1. Contoh Dugaan Respon Siswa dan Alternatif Respon Guru pada Kegiatan Ayo Menyimpulkan

Dugaan siswa dan alternatif respon guru yang disusun belum sepenuhnya bisa mencakup seluruh pemikiran siswa yang beragam. Hal ini dapat dilihat pada contoh jawaban yang di luar dari hipotesis seperti yang ada pada Gambar 2.

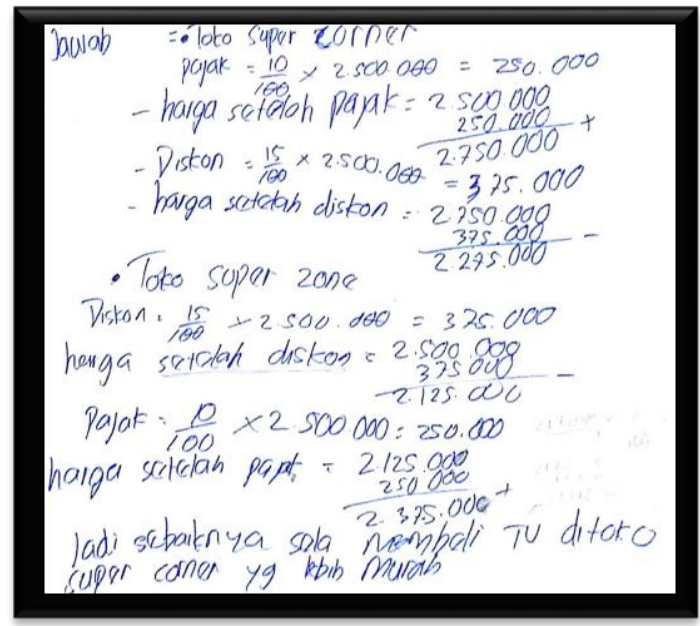

Gambar 2. Contoh Pekerjaan Siswa di Luar Dugaan Guru

Berdasarkan Gambar 2, siswa salah melakukan cara menentukan diskon dan pajak. Seharusnya pada pembelian di Toko Super Corner, diskon bukan hasil perkalian antara persentase diskon dengan besar harga awal akan tetapi diskon merupakan perkalian antara persentase diskon dengan harga setelah pajak. Hal ini juga terjadi pada penentuan besar pajak di Toko Super Zone.

Simon \& Tzur (2004: 93) berpendapat bahwa HLT bersifat dugaan yang belum tentu sesuai dengan proses yang terjadi, maka guru perlu memodifikasi setiap aspek dari HLT secara berkelanjutan. Hal ini selajan dengan temuan-temuan pada saat uji coba perangkat pembelajaran.

\section{Berdasarkan}

tahapan-tahapan penelitian yang telah dilaksanakan, 
penelitian ini telah menghasilkan perangkat pembelajaran dengan pendekatan PBL dan HLT yang berorientasi pada kemampuan penalaran matematis untuk siswa SMP kelas VII yang valid, praktis, dan efektif sehingga layak digunakan untuk pembelajaran matematika. Hasil penelitian ini sesuai dengan pendapat Retnawati \& Farhan (2014: 230) bahwa PBL kan mengantarkan siswa pada situasi masalah nyata yang dibutuhkan dalam proses pembelajaran untuk meningkatkan kemampuan siswa dalam pembelajaran matematika yakni salah satunya kemampuan penalaran. Savery (2006: 15) juga berpendapat bahwa PBL merupakan salah satu metode yang dapat meningkatkan kemampuan penalaran siswa.

Selain itu, perangkat pembelajaran yang menggunakan HLT dapat membantu siswa dalam mempelajari matematika lebih baik lagi. Clements \& Sarama (2009: p.ix) berpendapat bahwa guru yang memahami HLT pasti akan memahami pembelajaran matematika, memahami bagaimana siswa berpikir dan memahami bagaimana siswa belajar matematika, serta memahami bagaimana membantu siswa untuk mempelajari matematika dengan lebih baik. Lebih lanjut Clements \& Sarama (2015: 3) berpendapat bahwa guru yang menerapkan HLT, siswanya akan menunjukkan level penalaran matematis yang lebih tinggi.

\section{Penutup}

Penelitian pengembangan ini menghasilkan perangkat pembelajaran berupa RPP dan LKS dengan pendekatan PBL dan HLT yang berorientasi pada kemampuan penalaran matematis siswa dikembangkan dengan model pengembangan ADDIE yaitu Analysis, Design, Development, Implementation, dan Evaluation.

Perangkat pembelajaran dengan pendekatan PBL dan HLT yang berorientasi pada kemampuan penalaran matematis siswa yang telah dikembangkan layak digunakan ditinjau dari aspek kevalidan, kepraktisan, dan keefektifan.

Guru dapat menggunakan perangkat pembelajaran dengan pendekatan PBL dan HLT untuk memfasilitasi siswa belajar pada materi aritmetika sosial.

Perangkat pembelajaran dengan pendekatan PBL yang mengacu pada HLT telah terbukti valid, praktis, dan efektif untuk membantu siswa mengembangkan kemampuan penalaran matematis pada materi aritmetika sosial. Dengan demikian, dapat dilakukan penelitian serupa pada materi lain.

\section{Daftar PUstaka}

Arends, R.I. (2012). Learning to Teach. New York: McGraw-Hill.

Clements, D.H. \& Sarama, J. (2009). Learning and Teaching Early Math: The Learning Trajectory Approach. New York: Routledge

- (2015). What Are "Learning Trajectories" and How Do They Help? 
University of Denver: Morgridge College of Education.

Dick, W., \& Carey, L. (2009). The Systematic Design of Instruction (7th Ed.). New York: Harper Collins College Publishers.

Hamid, M.S. (2011). Metode Edutainment. Jogjakarta: Diva Press.

Julita. (2018). Peningkatan Kemampuan Pemecahan Dan Hasil Belajar Matematika Melalui Problem BasedLearning. Mosharafa: Jurnal Pendidikan Matematika, 7(1), 143154.

Kemendikbud. (2007). Peraturan Menteri Pendidikan Nasional Republik Indonesia Nomor 41 Tahun 2007 tentang Standar Proses untuk Satuan Pendidikan Dasar dan Menengah.

(2013). Peraturan Menteri Pendidikan dan Kebudayaan Nomor 23 Tahun 2013 tentang Standar Pelayanan Minimal Pendidikan Dasar di Kabupaten/Kota.

- (2017). Model Silabus Mata Pelajaran Sekolah Menengah Pertama/Madrasah Tsanawiyah (SMP/MTs).

Savery, J.R. (2006). Overview of problem based learning: definition and distinctions. The Interdisciplinary Journal of Problem Based Learning, 1(1), 9-20.

Miao, Y., Holst, S.J., Haake, J.M., et al. (2000). PBL-protocols: Guiding and Controlling Problem Based Learning Process in Virtual Learning Environment. GMD: Darmstad.
NCTM. (2000). Principles and Standards for School Mathematics. Reston: NCTM Inc.

Retnawati, H. \& Farhan, M. (2014). Keefektifan PBL Dan IBL Ditinjau Dari Prestasi Belajar, Kemampuan Representasi Matematis, Dan Motivasi Belajar. Jurnal Riset Pendidikan Matematika, 227-240.

Shadiq, F. (2004). Pemecahan Masalah, Penalaran dan Komunikasi. Yogyakarta: PPPG.

Simon, M. A. (1995). Reconstructing Mathematics Pedagogy from A Constructivist Perspective. Research in Mathematics Education, 26, 114-145.

Simon, M. A. \& Tzur, R. (2004). Explicating the Role of Mathematical Tasks in Conceptual Learning: An Elaboration of the Hypothetical Learning Trajectory. Mathematical Thinking and Learning, 6(2), 91-104.

Solihah, A. (2016). Pengaruh Model Pembelajaran Teams Games Tournament (TGT) Terhadap Hasil Belajar Matematika. Jurnal SAP 1(1), 45-53.

Wardhani, S. (2008). Analisis SI dan SKL Mata Pelajaran Matematika SMP/MTs Untuk Optimalisasi Pencapaian Tujuan. Yogyakarta: P4TK.

Widoyoko, E. P. (2017). Evaluasi Program Pembelajaran: Panduan Praktis Bagi Pendidik dan Calon Pendidik. Yogyakarta: Pustaka Pelajar.

World Bank. (2010). Inside Indonesia's Mathematics Classrooms: A Timss Video Study of Teaching Practices and 
Student Achievement. Jakarta: Sektor

Pengembangan Sumber Daya

Manusia.

\section{Riwayat Hidup PenUlis}

\section{Khoirudin, S.Pd.}

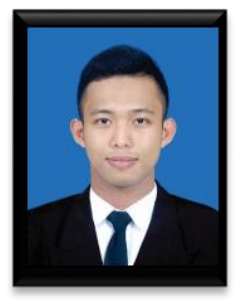

Lahir di Kulon Progo, 05 Juli 1996. Studi S1 Pendidikan Matematika Universitas Negeri Yogyakarta, lulus tahun 2018.

Ilham Rizkianto, S.Pd., M.Sc.

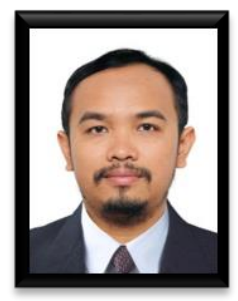

Lahir di Ponorogo, 08 Maret 1987. Dosen S1 di Pendidikan Matematika, Universitas Negeri Yogyakarta. Studi S1 Pendidikan Matematika Singaraja, lulus tahun 2009 dan studi S2 Pendidikan Matematika di UNSRI-UU,

lulus tahun 2012. 